\title{
Leucine Aminopeptidase from Arachis hypogaea L. Seeds Partial Purification and Characterization
}

\author{
TAGHREED U. MOHAMMD*1, LAYLA O. FARHAN², ASHGAN S. DAWOOD² \\ and BUSHRAF. HASAN ${ }^{2}$
}
'Department of Chemistry, College of Education for Pure Sciences, Ibn-AL-Haitham- University of Baghdad, Baghdad, Iraq. ${ }^{2}$ Department of Chemistry, College of Science for Woman, University of Baghdad, Baghdad, Iraq. *Corresponding author E-mail: tagreedaloom @ gmail.com http://dx.doi.org/10.13005/ojc/330567

(Received: July 19, 2017; Accepted: August 14, 2017)

\begin{abstract}
Leucine amino peptidases (LAP; EC 3.4.11.1) constitute a diverse set of exopeptidases that catalyze the hydrolysis of leucine residues from the amino-terminal of protein or peptide substrates, (LAP) are present in animals, plants, and microbes. In this study, leucine amino peptidase was purified partial from Arachis hypogaea seeds by using gel filtration chromatography Sephadex G-100. The enzyme was purified 3.965 fold with a recovery of $29.4 \%$. Its $\mathrm{pH}$ and temperature optimum were $(8.7)$ and $\left(37^{\circ} \mathrm{C}\right)$, respectively. The results show novel properties of LAP from Arachis hypogaea L. or peanut. The $\mathrm{Km}$ value for LAP $(77 \mathrm{mM})$, with $\mathrm{V}$ max $(1538 \mathrm{~m}$ mole $\mathrm{min}^{-1}$ ). We recommend a separate isoenzymeof the enzyme (LAP) from Arachis hypogaea on $\mathrm{L}$. peanut seeds and study the kinetic qualities of each of them
\end{abstract}

Keyword: Leucine amion peptidase (LAP), Arachis hypoaea L. seeds, Purification.

\section{INTRODUCTION}

Arachish ypogaea L. (Peanut) is one of seeds that has great quantity of oil and protein, therefor, it is considered as very important food legume to human nutrition in the world. We can find Arachish ypogaea L. (Peanut) widely distributed in the tropical and subtropical areas of the world ${ }^{1}$. It is an annual herbaceous plant growing (30-50) $\mathrm{cm}(1.0-1.6)$ feet tall. It has opposite leaves, pinnate with four leaflets (two oppositepairs; no terminal leaflet). The flowers of Arachis hypogaea $L$. are similar to typical pea flowers in shape, its color is yellow with reddish veining ${ }^{2}$. Biochemical, physiological, chemotaxonomy and gentic variability investigation studies make use of qualitative and quantitative isoenzymatic analysis. These studies benefit of a large number of plant population, cultivars and species $^{3}$.

Aminopeptidase (EC 3.4.11) is one of the group of proteases, important enzymes that play major role in many different life processes. The hydrolysis of amino acids can be catalyzed by using 
Aminopeptidase which found in the N-terminal of peptide and are involved in proteins degradation to free amino acids ${ }^{4}$. The major and greatest studied group of amino peptidase is Leucin amino peptdase (LAP, EC 3.4.11.1), especially in microorganisms and animals, therefor recognize it is $\mathrm{x}$-ray crystal structure and their nucleotide sequences ${ }^{5}$.

Generally, two classes of leucyl amino peptidases $\left(\mathrm{LAP}_{\mathrm{s}}\right)$ have been reported for most plant species $^{6}$. The first group has ther molabile amino peptidases with molecular weight of approximately 60-90 KDa and a neutral pH optimum. The second group are enzymes like plant $\mathrm{LAP}_{\mathrm{s}}$ but isolated from animals. With large (250-330 KDa), homohexamer icmet all opeptidases that contain ethylene diaminetetraacetic acid (EDTA) and be statin. They are heat stable and possess on alkaline $\mathrm{pH}$ optimum. LAP with alkaline $\mathrm{pH}$ optimum have been biochemically purified from a number of plants ${ }^{7}$. In the present study, we purified major LAP from Arachis hypogaea L. seeds and characterized its enzymoloical properties ( $\mathrm{pH}$ and temperature optimum).

\section{MATERIAL AND METHODS}

\section{Enzyme Extraction}

Arachis hypogaea L. (Imported from Turkey )was obtainedfrom a local super market in Baghdad, Iraq. Homogenizing $1 \mathrm{~g}$ homogenate at $18000 \mathrm{~g}$ for 30 of Arachis hypogaea seeds in $5 \mathrm{ml}$ of phosphate buffer, pH 7.8 use a Teflon pestle homogenizer were used for preparing crude extract. The supernatant was separated as crude after getting rid of insoluble debris by centrifuging $\min$. at $4^{\circ} \mathrm{C}$.

\section{Detrminations of protein concentration}

This method is based on the reaction of proteins with the alkaline sulphate followed by Folincicalteau reagent which produces a blue color complex due to the reaction of alkaline copper sulphate with the protein, the intensity of the color depends upon the quantity of the protein detected $^{8}$. As shown in Figure. (1).

\section{Determination of LAP activity}

hydrolysis of the peptide bond of leucinamide is measured according to Mitz and
Schlueter method spectrphotometrically at 238 $\mathrm{nm}$. Unit of enzyme activity like one micromole of L-lucinamide hydrolyzed per minute at $25^{\circ} \mathrm{C}$ and $\mathrm{pH} 8.5^{9}$.

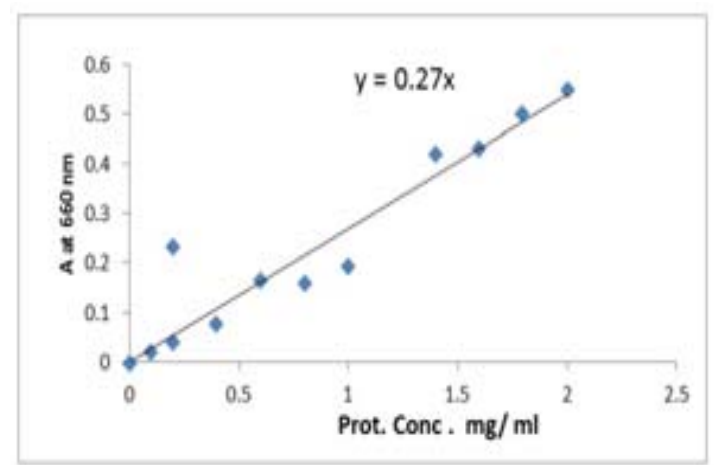

Fig. 1. Protein standard curve

\section{Parital purification of LAP}

Gel filtration chromatography using sephadex G-100 column was used for purification of partially purified enzyme. The height of $120 \mathrm{~cm}$ in a glass column with an internal diameter of $2.0 \mathrm{~cm}$ were used for packing the column, then equilibrated with $0.1 \mathrm{MT}$ ris- $\mathrm{HCl}$ buffer $\mathrm{pH}$ 8.5. The flow rate was at $0.5 \mathrm{ml} \mathrm{min}{ }^{-1}$. Forty fractions had been collected for each $2 \mathrm{ml}$ and both the protein content and the enzyme activity were determined for each separate fraction, as pointed out in the previous section.

\section{Effect of pH on LAP activity}

The effect of $\mathrm{pH}$ on LAP activity in the purified extract was firmed in different $\mathrm{pH}(8.1,8.3$, 8.5, 8.7, 8.9) with Tris- $\mathrm{HCl}$ buffer $\mathrm{pH}$ 8.5. Then LAP activity was measured.

Effect of temperature on LAP activity: Theeffect of temperature on LAP activity was firmed in different temperature $\left(20,24,37,40,45^{\circ} \mathrm{C}\right)$ with Tris- $\mathrm{HCl}$ buffer $\mathrm{pH}$ 8.5. Then LAP activity was measured.

\section{Different concentration of substrate}

Different concentration have been prepared $(45,85,125,165,205) \mathrm{m} \mathrm{M} / \mathrm{l}$ of substrate (leucinamide) in buffer ${ }^{9} \mathrm{Km}$ and $V \max$ for enzyme to substrate were determined by using the Lineweaver-Burk plot [the relationship between $1 / \mathrm{V}$ versus $1 /[\mathrm{S}]$. 


\section{RESULT AND DISCUSSION}

Table 1 summaries the result of partial purification of LAP from Arachis hypogaea. The supernatant with LAP activity of 1486.0 Unit $/ \mathrm{mL}$ and specific activity of 413.23 Unit/mg was considered as crude enzyme solution. This crude enzyme solution fraction was made up to a known volume, partially purified LAP was obtained from this crude enzyme solution fraction and loaded on sephadex G-100 gel filtration column.Gel filtration was purified to the enzyme 3.965 fold with a yield $29.4 \%$ and specific activity of 1638.75 Unit/mg. as shown Figure. (2).

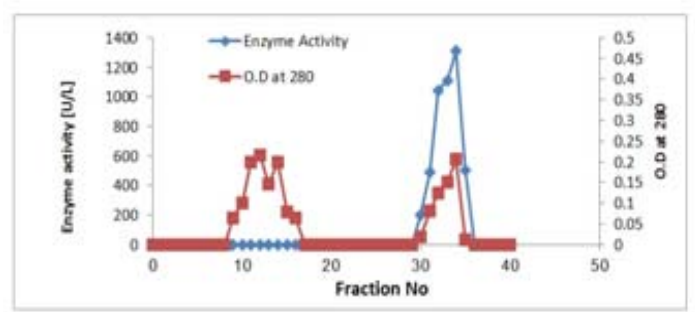

Fig. 2. Atypical elution profile for the chromatography leucin-aminopeptidase from Arachis hypogaeaon L. using Sephadex G-100

The exact role of $\mathrm{LAP}_{\mathrm{s}}$ in plants is not known, while it is enzymes take part in some important processes, such as protein mobilization from cotyledons after germination, and protein turnover required for cell maintenance in vegetative and reproductive organs ${ }^{10}$. $\mathrm{LAP}_{\mathrm{s}}$ are involved in rapid turnover of protein required in wounding or wounding or pathogen attack ${ }^{11}$.

The highest enzyme activity in the range of $\mathrm{pH}(8.1-8.9)$, with optimum activity in Tris- $\mathrm{HCl}$ buffer at $\mathrm{pH} 8.7$ was shown as in figure (3). This result was agree with the value got from Fasciola gigantic LAP at $\mathrm{pH} 8.0^{12}$, from Kiwifruit $\mathrm{pH} 9.0^{13}$. In comparison with, aromatic aminopeptidase which was isolated from grapes gave a result which was $\mathrm{pH} 7.0^{14}$, from barley $\mathrm{pH} 7.2^{15}$ and from wheat $\mathrm{pH}$

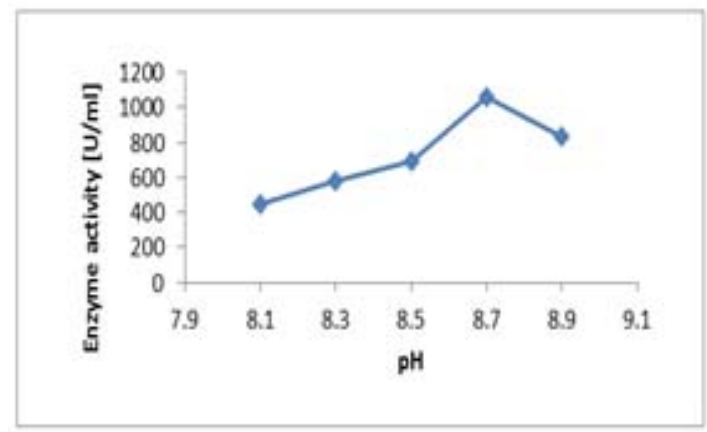

Fig. 3. Effect of pH on LAP activity

7.65. While Matsui et al., $2006^{9}$ showed that maximum activity was obtained at alkaline $\mathrm{pH}$ (8.0-11.0).

The optimum temperature for the activity of LAP from Arachis hypogaea L. seeds was determined to be $37^{\circ} \mathrm{C}$. as shown in Fig. (4). This result like the value obtained from pea shoots $37^{\circ} \mathrm{C}^{16,17}$. In the other studies kiwifruit AP was most

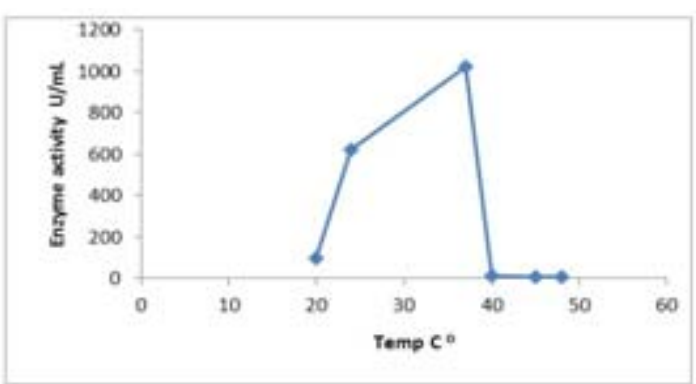

Fig. 4. Effect of temperature on LAP activity

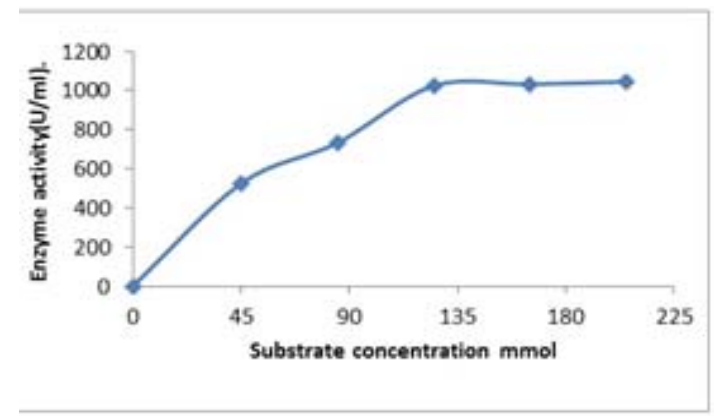

Fig. 5. Activity of LAP with different

Table. 1: Purification summary of aminopeptidaseArachis hypogaea.

\begin{tabular}{lccccccc}
\hline & $\begin{array}{c}\text { Volume } \\
\text { (ml) }\end{array}$ & $\begin{array}{c}\text { Activity } \\
\text { (Unit/ml) }\end{array}$ & $\begin{array}{c}\text { Total activity } \\
\text { (units) }\end{array}$ & $\begin{array}{c}\text { Total protein Specific activity } \\
\text { (mg/g) }\end{array}$ & $\begin{array}{c}\text { Fold } \\
\text { (Units/mg.) }\end{array}$ purification & Recovery \\
\hline Crude enzyme & 6 & 1486.0 & 8916 & 3.596 & 413.23 & 1 & 100 \\
Sephadex G-100 & 2 & 130107 & 2621.4 & 1.6 & 1638.75 & 3.965 & 29.4 \\
\hline
\end{tabular}




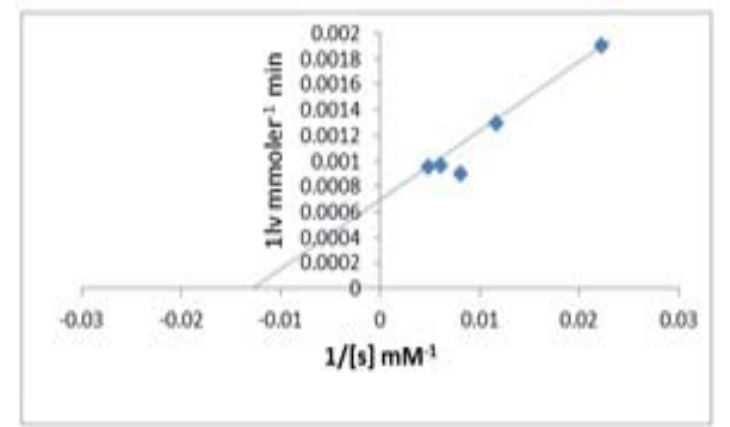

Fig. 6. Determination of $\mathrm{Km}$ and Vmax in partial purified enzyme .

active at $37^{\circ} \mathrm{C}^{13}$. Unlike stability of aromatic aminopeptidase, lucine aminopeptdases remained even at temperatures over $60^{\circ} \mathrm{C}$, an optimum temperature of $60-70^{\circ} \mathrm{C}$ was used for characterizing their activities ${ }^{9}$.
A linear relationship was obtained a Vmax [1538 $\mathrm{U} / \mathrm{mL}$ ] and $\mathrm{Km}$ value of [77 mM].An enzyme with low $\mathrm{Km}$ has a more affinity for its substrate.

\section{CONCLUSION}

In conclusion, in the present study,it was found one peak of the Arachishypogaeaon L.peanut enzyme (LAP) by chromatography(gel filtration ). The Arachi shypogaeaon $L$. peanut enzyme (LAP) reach optimum activity at $\mathrm{pH}$ is 8.7 and temperature at $37^{\circ} \mathrm{C}$. The purified enzyme indicated maximum

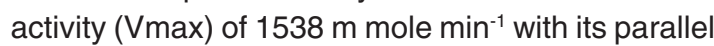
$\mathrm{Km}$ value of $77 \mathrm{Mm}$. We recommend a separate isoenzyme of the enzyme (LAP) from Arachis hypogaeaon $L$. peanut seeds and study the kinetic qualities of each of them. Note that the enzyme was purified for the first time and have got a successful and appropriate way because we got a good yield.

\section{REFERENCES}

1. Maria, L., and Catalina. R.L. .Isoenzimatic variability among five peanut cultivars. Bragantia.Campinas., 1994, 53(2),135-140.

2. Ryals, J.; Ward, E.; Ahl-Goy, P., and Metraux, J. P. . Inducible plant proteins: Society for Expermintal Biology Series, ed. Wary, J. L. (Cambridge Univ. Press, New York), 1992, $49,205-229$.

3. Cherry, J.P., and Ory, R.L. . Electrophoretic characterization of six selected enzymes of peanut cultivars. Phytochemistry, Oxford, 1973, 12(7), 283-289.

4. Joana, K., and Danuta. G. .Aminopeptidases isolated from plants of great economic valuerole and characteristics. Chemik., 2015, 69(8), 463-468.

5. Magda, P.; Urszula, S.;Wieslaw, B. and Edyta, Z. . Purification, biochemical characterization, and mass spectrometry analysis of phenylalanine aminopeptidase from the shoots of pea plants.Acta Physiol. Plant., 2011, 33, 609-617.

6. Zoran, V.; Bilijana, D.; Aleksandra, M. and Natasa, B. .Purification and Properties of the Major Lucyl aminopeptidase from Solanum tuberosum Tubers.Fruit, Vegetable and
Cereal Science and Biotechnology. Special Issue, 2008. 1., 125-130.

7. Matsui, M.; Fowler, HJ. and Walling, LL. . Lucine aminopeptidase: diversity in structure and function. Biological Chemistry., 2006, 387, 1535-1544.

8. Sadasivam, S. and Manikam, A. . In: Biochemical Methods for Agricultural Science, Wily Eastern Limited, New Delhi and TNAU, Coimbatore., India, 1992, 122-123.

9. Mitz, M. and Schlueter, R. Direct Spectrophotometric Measurement of the Peptide Bond: Application to the Determination of Acylase 1. Biochim. Biophys. Acta, 1958, 27, 168.

10. Park, SY. And Walling, LL.Isolation and characterization of the neutral leucine aminopeptidase (LapN) of tomato. Plant Physiology., 2003 132(1), 243-255.

11. Gu, YQ. and Walling, LL. Specificity of the wound- induced leucine aminopeptdase (LAP-A) of tomato activity on dipeptide and tripeptide substrates. European Journal of Biochemistry, 2000, 207(4),1178-1187.

12. Daniel, C.; Fernando G. and Carlos, C. Characterizayion and Partial Purification of a Leucine aminopeptidase From Fasciola 
hepatica. J. Parasitol., 1998, 84(1),1-7.

13. Permarathne, A.A. and David, W.M. Characterization of Activity of a Potential Food-Grade Lucine aminopeptidase from Kiwifruit. Enzyme Research, Articale ID, 2010, 51, 7283,1-5.

14. Mahagamasekera, M.G.P. and Leung, W.M. . Development of leucine aminopeptidase activity during dalily flower growth and senescence.Acta Physiologiae Plantarum, 2001, 23(2), 181-186.
15. Kang, H. C.; Hahn,T.-R.; Chung,I-S. and Park, JC. Characterization of aminopeptidase from grapes. Int J Plant Sci., 1999, 160 ,299-306.

16. Oszywa,B.; Makowski, M. and Pawelczak, M. . Purification and partial characterization of aminopeptidase from barley(Hordeum vulgare L.)seeds. Plant Physiol. Bioch., 2013, 65,75-80.

17. Ogiwara, N.; Amano, T.; Satoh, M. and Shioi, Y. . Lucine aminopeptidase from etiolated barley seedling: characterization and partial purification of isoforms. Plant Sci., 2005, 168, 575-581. 